\title{
Shallow and deep landslides induced by rainfall in the Lisbon region (Portugal): assessment of relationships with the North Atlantic Oscillation
}

\author{
J. L. Zêzere ${ }^{1}$, R. M. Trigo ${ }^{2,3}$, and I. F. Trigo ${ }^{4}$ \\ ${ }^{1}$ Centro de Estudos Geográficos, Universidade de Lisboa, Portugal \\ ${ }^{2}$ CGUL, Faculdade de Ciências, Universidade de Lisboa, Portugal \\ ${ }^{3}$ Departamento de Engenharias, Universidade Lusófona, Lisboa, Portugal \\ ${ }^{4}$ Instituto de Meteorologia, Lisboa, Portugal
}

Received: 26 October 2004 - Revised: 25 February 2005 - Accepted: 7 April 2005 - Published: 18 April 2005

Part of Special Issue "Landslides and debris flows: analysis, monitoring, modeling and hazard"

\begin{abstract}
The aim of this study is to assess the impact of the North Atlantic Oscillation (NAO) on both the winter precipitation and the temporal occurrence of different landslide types in Portugal. The analysis is applied to five sample areas located just north of Lisbon, the capital of Portugal. These sites are particularly relevant because actual dates of most of the recent landslide events are known but also because the landslides occurred in a suburban area with growing urbanization pressure.
\end{abstract}

Results show that the large inter-annual variability of winter precipitation observed in western Iberia, i.e. Portugal and parts of Spain, is largely modulated by the NAO mode. In particular, precipitation falling in Portugal between November and March presents a correlation coefficient of $R=-0.66$ with the NAO index. Precipitation distribution for the reference rain gauge in the study area reveals that the probability of a wet month to occur is much higher for low NAO index composites than for the corresponding high NAO index composite. It is shown that this control, exerted by NAO on the precipitation regime, is related to corresponding changes in the associated activity of North-Atlantic storm tracks that affect the western Iberia.

Landslide activity in the study area is related to both intense, short duration precipitation events (1-15 days) and long-lasting rainfall episodes (1-3 months). The former events trigger shallow translational slides while the later episodes are usually associated with deeper and larger slope movements. This second group of landslides is shown to be statistically associated with the 3-month average of the NAO index.

Correspondence to: J. L. Zêzere

(jlzezere@fl.ul.pt)

\section{Introduction}

Portugal is prone to slope instability due to geological, geomorphological and climatic factors (Rodrigues and Coelho, 1989; Ferreira and Zêzere, 1997). In the area north of Lisbon studied in this paper, landslides have caused considerable economic losses during the last 50 years. Landslide consequences include damages on property, houses and particularly roads, and are strongly related with the increasing human pressure related to urban development around the Portuguese capital. In fact, human activity within the region has introduced significant land use changes, which are partially responsible for the acceleration of natural geomorphologic activity during the previous half century (Ferreira et al., 1987; Zêzere, 2002).

Slope movements in the Lisbon area are induced by rainfall, as are most landslides worldwide (Fukuoka, 1980; Crozier, 1986; Gostelow, 1991; Corominas, 2001). The role of precipitation on landslide activity near Lisbon has been discussed and analysed in previous works (Zêzere et al., 1999a, 1999b; Zêzere, 2000; Zêzere and Rodrigues, 2002), by applying cumulative rainfall methods. Previous results obtained using empirical relationships between rainfall amount and duration, and slope instability show that critical rainfall conditions for failure are not the same for different types of landslide movement (Zêzere, 2000; Zêzere and Rodrigues, 2002; Trigo et al., 2005). Shallow translational soil slips are most commonly activated by intense precipitation that falls within the 1 to 15 days long range. On the contrary, activity of the more deeply-seated landslides of rotational, translational and complex types is related to successive weeks of nearly constant rainfall, over periods of 30 to 90 days. The physical explanation of the different behaviour of shallow and deep landslides is probably related 
Table 1. Main slope movements and basic morphometrical parameters of the landslides identified in 5 study areas $\left(61.6 \mathrm{~km}^{2}\right)$ in the region north of Lisbon.

\begin{tabular}{|c|c|c|c|c|c|c|c|c|c|c|}
\hline \multirow[t]{2}{*}{$\begin{array}{c}\text { Type of } \\
\text { movements }\end{array}$} & \multirow[t]{2}{*}{$\begin{array}{l}\text { number } \\
\text { of cases }\end{array}$} & \multirow{2}{*}{$\begin{array}{c}\% \text { of total } \\
\text { landslides } \\
\text { events }\end{array}$} & \multicolumn{2}{|c|}{$\begin{array}{c}\text { slope angle } \\
\left({ }^{\circ}\right)\end{array}$} & \multicolumn{2}{|c|}{$\begin{array}{l}\text { depth } \\
\text { (m) }\end{array}$} & \multicolumn{2}{|c|}{$\begin{array}{l}\text { area per landslide } \\
\qquad\left(\mathrm{m}^{2}\right)\end{array}$} & \multicolumn{2}{|c|}{$\begin{array}{l}\text { estimated volume } \\
\text { per landslide }\left(\mathrm{m}^{3}\right)\end{array}$} \\
\hline & & & mean & std. dev. & mean & std. dev. & mean & std. dev. & mean & std. dev \\
\hline $\begin{array}{l}\text { shallow translational } \\
\text { slide }\end{array}$ & 212 & 58.9 & 23 & 8 & 1.0 & 0.5 & 552 & 693 & 286 & 376 \\
\hline $\begin{array}{l}\text { translational } \\
\text { slide } \\
\text { rotational }\end{array}$ & 55 & 15.3 & 17 & 7 & 3.1 & 1.7 & 4059 & 5470 & 5232 & 8822 \\
\hline $\begin{array}{l}\text { slide } \\
\text { complex and composite }\end{array}$ & 39 & 10.8 & 19 & 7 & 5.2 & 4.3 & 9407 & 21664 & 34843 & 116434 \\
\hline $\begin{array}{l}\text { movements } \\
\text { total }\end{array}$ & 54 & 15.0 & 20 & 8 & 4.0 & 3.4 & 9747 & 27011 & 42998 & 202801 \\
\hline landslides & 360 & 100.0 & 21 & 8 & 2.1 & 2.5 & 4481 & 18241 & 12224 & 82489 \\
\hline
\end{tabular}

to infiltration processes, namely the different pressure head responses to rainfall controlled by soil characteristics, slip surface depths and effective hydraulic diffusivities (Iverson, 2000). Here we improve the empirical discrimination between precipitation events that trigger shallow and deep slope movements in the study area, taking in account the different landslide mechanisms.

The present study aims at characterizing the atmospheric conditions that favor the occurrence of landslides in the study area, particularly those slope movements associated with long-lasting rainfall episodes. Therefore, a comprehensive description of the precipitation regime at the regional (Portugal) and local (Lisbon area) scales, particularly the interannual variability of precipitation, is examined here to understand the temporal variation of landslide activity.

The North Atlantic Oscillation (NAO) has been recognized for more than 70 years as one of the major patterns of atmospheric variability in the Northern Hemisphere (Walker, 1924). However, only in recent years has this important atmospheric circulation mode become the subject of a wider interest (e.g. van Loon and Rogers, 1978; Rogers, 1984; Barnston and Livezey, 1987). More recently, the study by Hurrell (1995) had significant impact on the climatological community and has been followed by an increasing number of studies. It is within this context, that several studies have established links between the NAO index and winter season precipitation in Western Europe and, in particular, over the Mediterranean basin (Hurrell, 1995; Qian et al., 2000; Trigo et al., 2004a). This control exerted by NAO on the precipitation field over Europe is likely related to corresponding changes in the associated activity of North Atlantic storm tracks (Serreze et al., 1997; Osborn et al., 1999). In fact, this strong NAO-precipitation link has been used to develop rainfall forecast models that predict precipitation in Iberia several months in advance (e.g. Gámiz-Fortis et al., 2002; Rodriguez-Fonseca and Castro, 2002). The output of these models may provide useful seasonal forecasting tools for wa- ter resource managers and risk assessment teams (Trigo et al., 2004a).

The relationship between landslide activity and low frequency atmospheric circulation patterns (associated with anomalous precipitation at the seasonal scale), has been undertaken before using the Southern Oscillation, better known as El Niño. Recent El Niño events, such as those occurred in 1982/1983 and 1997/1998 were directly responsible for anomalously high precipitation in different parts of the Globe. The unusual rainfall produced widespread landslide activity in unrelated regions, such as California (Coe et al., 1998; Godt, 1999) and Kenya (Ngecu and Mathu, 1999). To the best of our knowledge no similar study has been published for any European region, despite the fact that the NAO exerts a significant control on the precipitation regime in southern Europe.

Therefore, the main objectives of this study are:

(i) to describe the main characteristics of episodes of landslide activity observed during the previous 50 years, in several locations north of Lisbon;

(ii) to discriminate precipitation events responsible for shallow and deep landslides using empirical analytical tools;

(iii) to characterize the impact of NAO on the location of cyclones that strike Iberia, as well as the impact of NAO on the precipitation regime at the regional (Portugal) and local (north of Lisbon) scales;

(iv) to assess the influence of the NAO on the occurrence of landslides near Lisbon, in particular the deeper slope movements triggered by long duration rainfall events.

\section{Geomorphologic setting}

The region north of Lisbon (Fig. 1) is located in the Portuguese Meso-Cenozoic sedimentary basin, and has a general monocline structure dipping $5^{\circ}$ to $25^{\circ}$ towards south and southeast. Geological formations include very heterogeneous lithological units (e.g. limestones, marly limestones, 


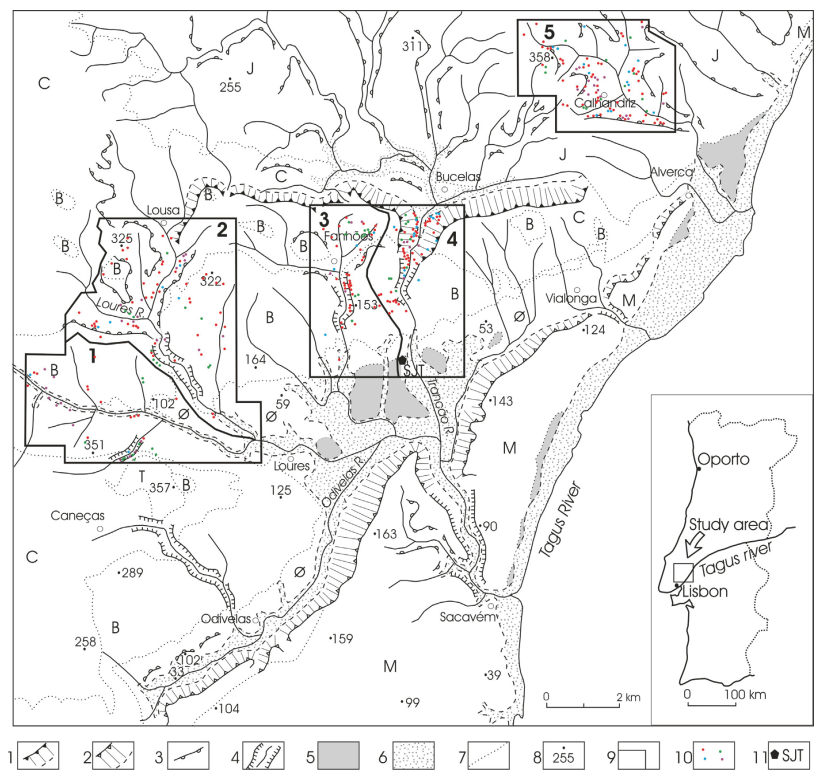

Fig. 1. Geomorphological map of the Area North of Lisbon. 1. Front of "cuesta" on Cretaceous rocks; 2. Front of "cuesta" on Tertiary rocks; 3. Other cliffs; 4. River and gorge; 5. Terrace; 6. Alluvial plain; 7. Geological boundary; 8. Elevation in meters; 9. Sample areas; 10. Landslides: shallow translational slides (red), translational slides (green), rotational slides (cyan), complex and composite slope movements (purple); 11. Location of S. Julião do Tojal rain-gauge. J. Jurassic rocks (clays, marls, limestones, sandstones); C. Cretaceous rocks (sandstones, marls and limestones); B. Upper Cretaceous Volcanic Complex of Lisbon; O. Paleogene detritic complex; M. Miocene (sandtones, limestones and clays). 1 - Pinheiro de Loures Sample Area; 2 - Lousa Sample Area; 3 Fanhões Sample Area; 4 - Trancão Sample Area; 5 - Calhandriz Sample Area.

marls and clays, sandstones, basalts and volcanic tufs) dating from the upper Jurassic to Miocene. The region north of Lisbon contacts the Tagus basin south-eastward along the Low Tagus fault zone (NE-SW direction). The tectonic activity of this structure has been responsible for the regional uplift of the study area during the previous $5 \mathrm{M}$ years (Ferreira et al., 1987; Zêzere et al., 1999b). This positive tectonic deformation explains the strong fluvial erosion and development of steep slopes, namely on those valleys running in the same direction of the dip of strata. Outcropping rocks were differentially eroded during the Quaternary, allowing the development of "cuestas" and large depressions like the Loures basin, where quaternary age sediments are preserved.

\section{Landslide identification and classification}

Landslides were mapped and inventoried in 5 study areas with a total area of $61.6 \mathrm{~km}^{2}$ (Fig. 1). Within these five areas 360 slope movements were identified, excluding rockfalls and landslides triggered by bank erosion of stream channels. Therefore, the landslide density is 5.8 per $\mathrm{km}^{2}$ and the total affected area is more than $1.6 \mathrm{~km}^{2}(2.6 \%$ of the total

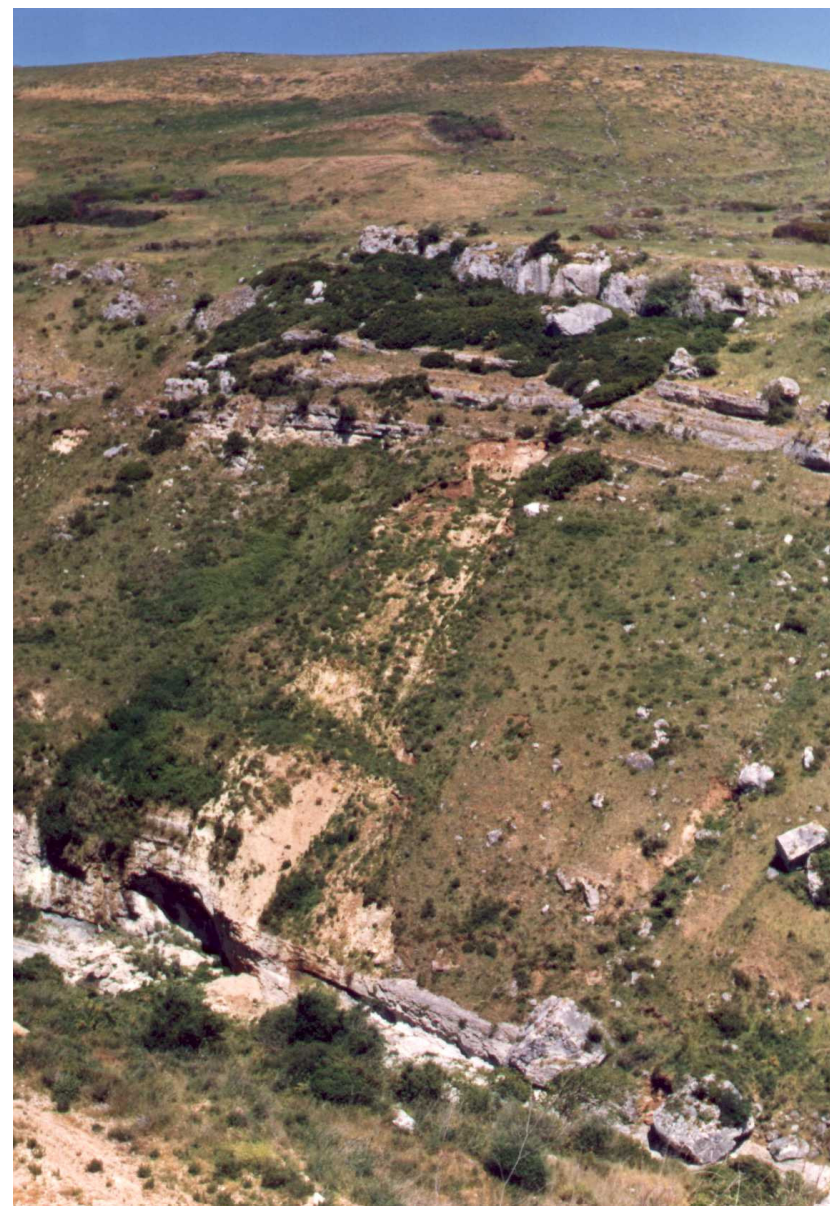

Fig. 2. Shallow translational slide triggered in November 1983, in the East slope of the Trancão valley (Trancão sample area).

study area). Landslides were classified in four main groups (Table 1), taking into account the type of movement and the affected material (Zêzere et al., 1999a, 1999b).

\subsection{Shallow translational slides}

Shallow translational slides are the most frequent slope movements within the study area $(59 \%$ of total landslide events). They are single slope movements with planar slip surfaces, and generally have small lateral dimension (mean area, $552 \mathrm{~m}^{2}$; mean volume, $286 \mathrm{~m}^{3}$ ).

In most of cases, shallow landslides occur on steep valley hill slopes (mean slope angle $=23^{\circ}$ ) and affect soil material (colluvium deposits) covering impermeable rocks, such as volcanic tuffs, marls and clays (Fig. 2).

\subsection{Translational slides}

Translational slides are generally deeper seated and larger than shallow movements (mean area $4059 \mathrm{~m}^{2}$; mean volume $5232 \mathrm{~m}^{3}$ ). These landslides typically involve the bedrock (marls and clays with limestone and marly limestone intercalations) and activate on slopes that follow the dip of the 


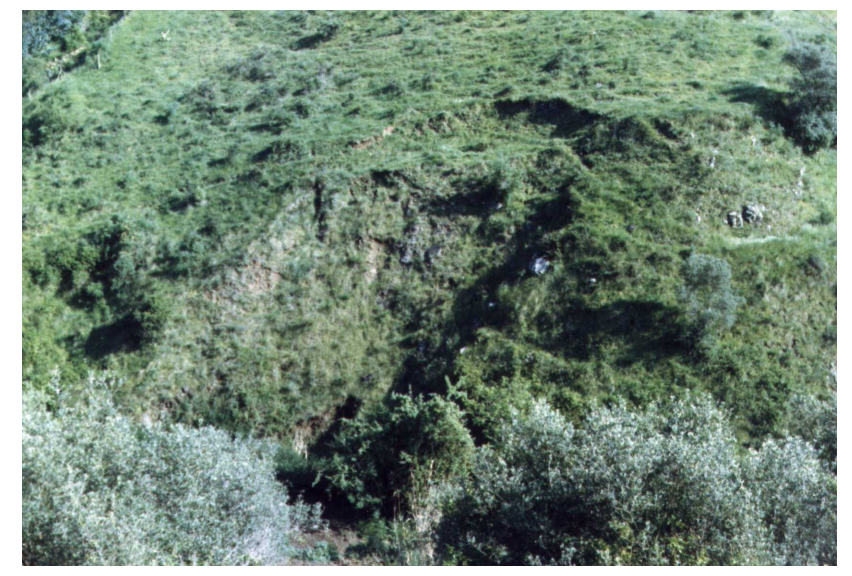

Fig. 3. Translational slide occurred in February 1979, on a cataclinal slope where basalts overlay volcanic tuffs (Pinheiro de Loures sample area).

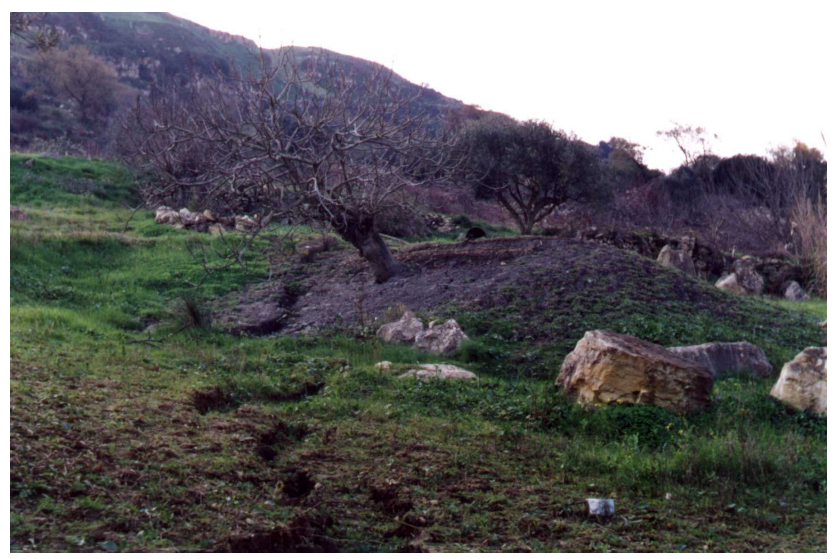

Fig. 4. Backward scarp of a confined rotational slide triggered in December 1989. The landslide took place on a gentle slope cutting clays and marls of Jurassic age (Calhandriz sample area).

strata, along shear surfaces controlled by impermeable bedding planes (Fig. 3). Translational slides are strongly conditioned by geometrical factors, as it is confirmed by the gradient of the affected slopes (average $=17^{\circ}$ ), which exceeds the dip of the strata in more than $85 \%$ of cases.

Although topographic slope has a relatively minor effect on the infiltration capacity of soils (Philip, 1991), moderate slope gradients do not favour rapid drainage of water by both overland flow and sub-surface flow, thus contributing to slope instability.

\subsection{Rotational slides}

Rotational slides are not particularly common in the study area ( $11 \%$ of the total slope movements) due to the inhomogeneous and anisotropic characteristic of most geological formations. The presence of zones of weakness (e.g. soft bedding planes) is a condition facilitating the development of planar slip surfaces rather than circular rupture zones. There-

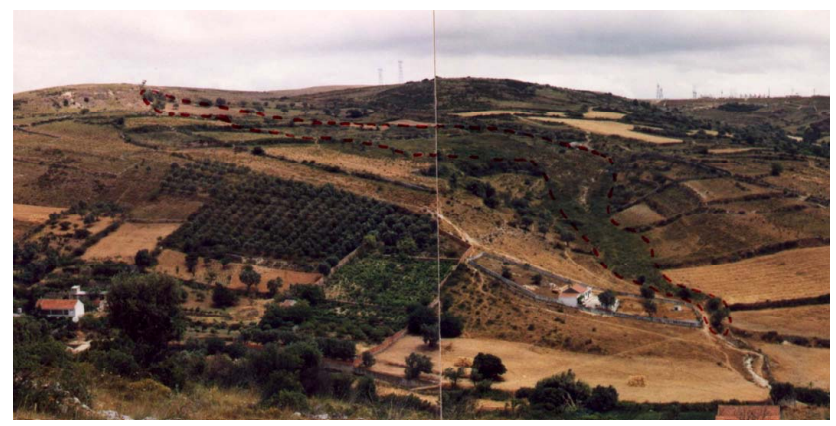

Fig. 5. General overview of the "Quebradas" complex slope movement (Fanhões sample area). The landslide developed in February 1979 as a deep translational slide, evolving downslope to an earthflow.

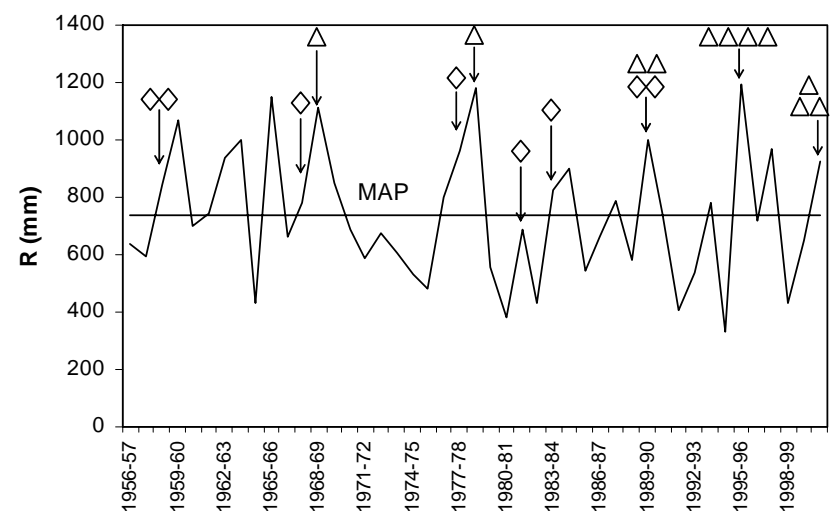

Fig. 6. Annual precipitation (climatological year) distribution at S. Julião do Tojal (reference rain-gauge) from 1956/1957 to 2000/2001. The horizontal line indicates the mean annual precipitation (MAP). Diamonds indicate episodes of shallow landslides activity and triangles indicate episodes of deep landslides activity.

fore, rotational slides develop on the mostly homogeneous lithological units (clays and marls) within the Calhandriz study area, where it is possible to observe rotational slides of single, confined and multiple retrogressive sub-types (Fig. 4).

Rotational slides have the highest average depth $(5 \mathrm{~m})$ and are typically larger than the translational movements (mean area $9407 \mathrm{~m}^{2}$; mean volume $34843 \mathrm{~m}^{3}$ ).

\subsection{Complex and composite slope movements}

Landsides included in this category show at least two different types of mechanisms, in sequence (complex movement) or simultaneously (composite movement). The most significant examples combine slide and flow mechanisms as well as translational and rotational movements (Fig. 5).

Most of the larger landslides that occurred in the study area during the previous 50 years belong to this type. Together with the rotational slides, this landslide group exhibits the largest average area and volume $\left(27011 \mathrm{~m}^{2} ; 42998 \mathrm{~m}^{3}\right)$. 


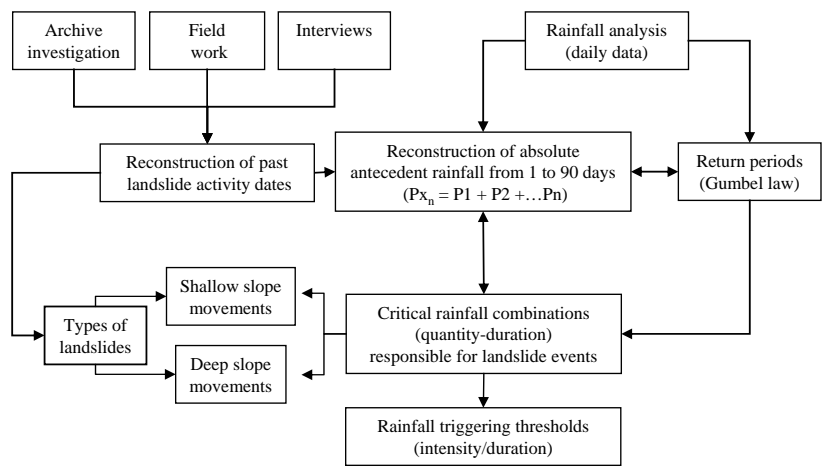

Fig. 7. Methodology for the statistical analysis of rainfall triggering of landslides based on the reconstruction of absolute antecedent precipitations.

\section{Temporal occurrence of rainfall triggered landslides}

\subsection{Rainfall regime}

The Portuguese precipitation regime is dominated by high variability at both the inter-annual and inter-seasonal scales. The strong seasonal cycle, typical of most Mediterranean climates, is characterized by the concentration of precipitation during the months between October and March, and with little or no rainfall during the dry summer months (Trigo and DaCamara, 2000). The mean annual precipitation (MAP) at the reference rain gauge of S. Julião do Tojal (SJT, Fig. 1) is roughly $730 \mathrm{~mm}$, with the rainfall occurring mostly from October to March (78\% of the total amount; $72 \%$ of the total rainy days). Even at the annual scale, the rainfall regime is very irregular (Fig. 6), alternating large periods of drought with prolonged rainy periods. Very intense rainfall episodes occur episodically (e.g. in November 1967 and November 1983; return period $\geq 60$ years), causing catastrophic flash floods on small catchments and widespread shallow slope movements on steep slopes.

\subsection{Reconstruction of absolute antecedent rainfall}

Recent landslides in the region north of Lisbon were induced by rainfall, and landslide activity has been confined to very wet periods (Ferreira et al., 1987). Figure 7 shows the general methodology used to assess the relationship between absolute antecedent rainfall and landslide occurrence, based on previous work carried out for the studied area (Zêzere et al., 1999a, 1999b; Zêzere, 2000; Zêzere and Rodrigues, 2002). As a first step, the dates of landslide activity were reconstructed from field work, archive investigation and interviews with the population living in the study area. This reconstruction also includes the particular type(s) of landslide(s) activated in each event. Rainfall analysis was carried out using 45 years (1956-2001) of daily precipitation at SJT, which is considered representative for the study area (Zêzere, 2000; Zêzere and Rodrigues, 2002). The analysis consists of calculating the cumulative absolute antecedent rainfall for 1, 5, 10,

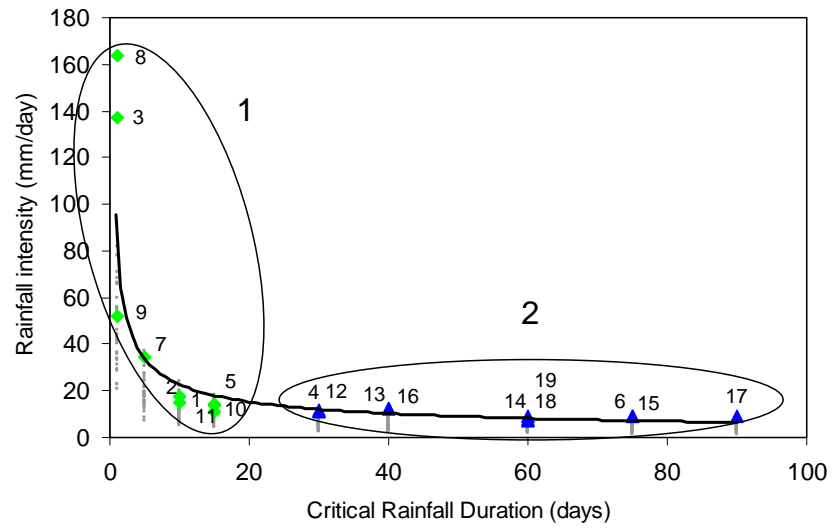

Fig. 8. Regression line between critical rainfall intensity and corresponding event duration (period 1956-2001). Green diamonds: values associated to shallow landslide episodes. Blue triangles: values associated to deep landslide episodes. Small dots: values obtained from the yearly maximum rainfall intensity for all duration intervals (computed for years without reported landslides).

$15,30,45,60,75$ and 90 consecutive days prior to the dates of confirmed landslide activity during the 45 years period. The return period of the rainfall amount-duration combinations was computed using a Gumbel distribution (Gumbel, 1958). The critical rainfall combination (quantity-duration) responsible for each landslide event was assessed, assuming as critical pair the combination with the higher return period. This assumption has not a physical basis, but provides a maximum discrimination between rainfall periods characterized by landslide activity and rainfall periods not related with slope instability.

Nineteen major rainfall episodes that triggered landslides were identified (Fig. 6), some of which were from the same climatological year (e.g. December 1958, March 1959). Nine of these episodes were dominated by shallow landslides, while the remaining where marked by occurrence of deepseated slope movements. The most relevant features of each landslide event are shown in Table 2, including date, rainfall amount-duration, and rainfall intensity-duration relationships.

To analyse the overall effect of precipitation on landslide activity we combine the rainfall intensity and the critical rainfall duration for the 19 reported landslide events (large diamonds and triangles in Fig. 8). A regression analysis shows that rainfall intensity increases exponentially as duration decreases, following the equation $R i=84.3 D^{-0.57}$, where $R i$ is the rainfall intensity in $\mathrm{mm} /$ day and $D$ is the duration of rainfall in days.

The maximum yearly value for durations of $1,5,10,15$, $30,40,60,75$ and 90 days were also computed for the 34 years for which no landslide activity was reported. These values are also plotted in Fig. 8 (small dots) and the vast majority of them lie below the fitted curve. Therefore, the regression curve is a reliable rainfall intensity - duration threshold for the study area. Nonetheless, we emphasize that this rain- 
Table 2. Temporal occurrence of rainfall triggered landslides in the region north of Lisbon from 1956 to 2001 . (a) Shallow landslide episodes; (b) Deep landslide episodes.

\begin{tabular}{ccccc}
\hline $\begin{array}{c}\text { Landslide } \\
\text { episode \# }\end{array}$ & $\begin{array}{c}\text { Date } \\
(\mathrm{dd} / \mathrm{mm} / \text { yyyy })\end{array}$ & $\begin{array}{c}\text { Critical rainfall } \\
\text { amount duration } \\
\text { mm (dd) }\end{array}$ & $\begin{array}{c}\text { Rainfall } \\
\text { intensity duration } \\
\text { mm/day (dd) }\end{array}$ & $\begin{array}{c}\text { Return } \\
\text { period } \\
\text { (years) }\end{array}$ \\
\hline (a) & & & & \\
1 & $19 / 12 / 1958$ & $149(10)$ & $14.9(10)$ & 2.5 \\
2 & $09 / 03 / 1959$ & $175(10)$ & $17.5(10)$ & 4 \\
3 & $15 / 11 / 1967$ & $137(1)$ & $137.0(1)$ & 60 \\
5 & $04 / 03 / 1978$ & $204(15)$ & $13.6(15)$ & 3.5 \\
7 & $30 / 12 / 1981$ & $174(5)$ & $34.7(5)$ & 13 \\
8 & $18 / 11 / 1983$ & $164(1)$ & $164.0(1)$ & 200 \\
9 & $25 / 02 / 1987$ & $52(1)$ & $52.0(1)$ & 2 \\
10 & $22 / 11 / 1989$ & $164(15)$ & $11.0(15)$ & 2 \\
11 & $25 / 11 / 1989$ & $217(15)$ & $14.4(15)$ & 4.5 \\
& & & & \\
(b) & & & & 6.5 \\
4 & $15 / 11 / 1968$ & $350(30)$ & $11.7(30)$ & 20 \\
6 & $10 / 02 / 1979$ & $694(75)$ & $9.2(75)$ & 5.5 \\
12 & $05 / 12 / 1989$ & $333(30)$ & $11.1(30)$ & 20 \\
13 & $21 / 12 / 1989$ & $495(40)$ & $12.4(40)$ & 10 \\
14 & $09 / 01 / 1996$ & $544(60)$ & $9.1(60)$ & 18 \\
15 & $23 / 01 / 1996$ & $686(75)$ & $9.1(75)$ & 20 \\
16 & $28 / 01 / 1996$ & $495(40)$ & $12.4(40)$ & 5.5 \\
17 & $01 / 02 / 1996$ & $793(90)$ & $8.8(90)$ & 24 \\
18 & $06 / 01 / 2001$ & $447(60)$ & $7.4(60)$ & $5.8(60)$ \\
19 & $09 / 01 / 2001$ & $467(60)$ & & \\
\hline
\end{tabular}

fall threshold is statistically based and was not defined considering the hydrological response to rainfall of the soil and local slope stability conditions.

For shorter duration rainfall events (Group 1, Fig. 8), the rainfall intensity required to trigger landslides is highly dependent on the duration of the precipitation event (e.g. $23 \mathrm{~mm} /$ day for 10 days; $84 \mathrm{~mm} /$ day for 1 day). In contrast, for long duration precipitation periods (above 30 days consecutive rainfall, Group 2, Fig. 8) the daily rainfall intensity tends to stabilize around the $8-12 \mathrm{~mm} / \mathrm{day}$.

\subsection{Reconstruction of calibrated antecedent rainfall}

According to Canuti et al. (1985) and Crozier (1986), the impact of a particular rainy event decreases in time due to drainage processes. In order to consider that effect in rainfalllandslide analysis, Canuti et al. (1985) developed an index for sites in Italy that accounts for the calibrated cumulative rainfall, where the most recent data are given a higher weight. A similar approach was developed by Crozier (1986) and applied by Glade et al. (2000) to sites in New Zealand, which accounts for the draining of early precipitation and accumulation of late rainfall.

In this work, antecedent rainfall was weighted using the formula proposed by Crozier (1986):

$\mathrm{CAR} x=K P_{1}+K^{2} P_{2}+\ldots K^{n} P_{n}$ where CAR $x$ is the calibrated antecedent rainfall for day $x$; $P_{1}$ is the daily rainfall for the day before day $x ; P_{n}$ is the daily rainfall for the $n$-th day before day $x$. The constant $K$ is an empirical parameter usually considered between 0.8 and 0.9 , depending on the draining capacity of the material and the hydrological characteristics of the area (Capecchi and Focardi, 1988). Following the work developed previously, in the present study it was assumed $K=0.9$ (Zêzere, 2000). This constant makes rainfall occurring more than 30 days before a landslide event to become negligible (Capecchi and Focardi, 1988). Therefore, the reconstitution of calibrated antecedent rainfall was only performed for durations of $3,5,10,15$ and 30 days.

Table 3 summarizes results of calibrated antecedent rainfall for both shallow landslide episodes (Table 3a) and deep landslide episodes (Table $3 \mathrm{~b}$ ). This distinction between landslide types is also considered in Figs. 9 and 10, where the evaluation of triggering rainfall conditions was made combining the calibrated antecedent rainfall for 5 and 30 days and the daily rainfall data.

In order to define the number of days relevant to the antecedent rainfall, we combine the daily rainfall relative to the 19 reported landslide events with the corresponding calibrated antecedent rainfall for different periods (green diamonds and blue triangles for shallow landslides and deep landslides, respectively, in Fig. 11). Besides shallow and deep landslide events, Fig. 11 includes also the maximum 
Table 3. Calibrated antecedent rainfall (CAR) for periods of landslide activity in the region north of Lisbon from 1956 to 2001 . (a) Shallow landslide episodes; (b) Deep landslide episodes.

\begin{tabular}{|c|c|c|c|c|c|c|c|c|}
\hline \multirow[b]{2}{*}{$\begin{array}{l}\text { Landslide } \\
\text { episode \# }\end{array}$} & \multirow[b]{2}{*}{$\begin{array}{c}\text { Date } \\
(\mathrm{dd} / \mathrm{mm} / \text { yyyy })\end{array}$} & \multicolumn{6}{|c|}{ Calibrated antecedent rainfall (CAR) } & \multirow[b]{2}{*}{$\begin{array}{c}\text { \# of previous } \\
\text { consecutive days } \\
\text { with } 30 \text {-days CAR } \\
\quad>50 \mathrm{~mm}\end{array}$} \\
\hline & & $\begin{array}{c}\text { Daily } \\
\text { rainfall } \\
(\mathrm{mm})\end{array}$ & $\begin{array}{c}3 \\
\text { days } \\
(\mathrm{mm})\end{array}$ & $\begin{array}{c}5 \\
\text { days } \\
(\mathrm{mm})\end{array}$ & $\begin{array}{c}10 \\
\text { days } \\
(\mathrm{mm})\end{array}$ & $\begin{array}{c}15 \\
\text { days } \\
(\mathrm{mm})\end{array}$ & $\begin{array}{c}30 \\
\text { days } \\
(\mathrm{mm})\end{array}$ & \\
\hline \multicolumn{9}{|l|}{ (a) } \\
\hline 1 & $19 / 12 / 1958$ & 22.0 & 54.2 & 73.6 & 91.7 & 99.2 & 108.5 & 6 \\
\hline 2 & 09/03/1959 & 45.5 & 27.5 & 55.4 & 82.2 & 82.2 & 83.6 & 4 \\
\hline 3 & $25 / 11 / 1967$ & 137.0 & 4.1 & 4.1 & 10.3 & 16.3 & 25.2 & 0 \\
\hline 5 & 04/03/1978 & 14.5 & 43.9 & 67.1 & 93.8 & 105.0 & 109.8 & 8 \\
\hline 7 & $30 / 12 / 1981$ & 78.0 & 75.5 & 75.5 & 102.6 & 109.5 & 111.3 & 3 \\
\hline 8 & $18 / 11 / 1983$ & 163.7 & 42.1 & 59.8 & 88.2 & 96.7 & 103.8 & 10 \\
\hline 9 & $25 / 02 / 1987$ & 51.8 & 22.2 & 35.4 & 36.0 & 46.5 & 52.1 & 1 \\
\hline 10 & $22 / 11 / 1989$ & 33.5 & 19.9 & 50.7 & 62.9 & 70.9 & 72.1 & 4 \\
\hline 11 & $25 / 11 / 1989$ & 38.0 & 36.9 & 42.7 & 75.7 & 88.5 & 89.1 & 7 \\
\hline \multicolumn{9}{|l|}{ (b) } \\
\hline 4 & $15 / 11 / 1968$ & 45.5 & 43.4 & 47.3 & 74.3 & 92.3 & 107.7 & 18 \\
\hline 6 & $10 / 02 / 1979$ & 26.0 & 89.3 & 93.6 & 110.1 & 119.7 & 133.6 & 17 \\
\hline 12 & 05/12/1989 & 30.1 & 58.1 & 58.1 & 78.8 & 93.7 & 109.7 & 17 \\
\hline 13 & $21 / 12 / 1989$ & 26.7 & 29.1 & 40.5 & 65.3 & 78.2 & 100.9 & 33 \\
\hline 14 & 09/01/1996 & 66.5 & 17.8 & 29.5 & 54.2 & 79.5 & 88.4 & 17 \\
\hline 15 & 23/01/1996 & 23.6 & 36.5 & 38.7 & 53.2 & 78.9 & 96.8 & 31 \\
\hline 16 & 28/01/1996 & 25.5 & 9.2 & 30.9 & 53.7 & 62.3 & 85.6 & 36 \\
\hline 17 & 01/02/1996 & 24.5 & 34.5 & 48.6 & 69.1 & 79.9 & 97.9 & 40 \\
\hline 18 & 06/01/2001 & 24.5 & 22.7 & 39.1 & 53.7 & 79.1 & 87.4 & 17 \\
\hline 19 & 09/01/2001 & 16.0 & 22.1 & 38.6 & 51.9 & 67.1 & 85.3 & 20 \\
\hline
\end{tabular}

yearly precipitation in one day (pink dots) and the maximum yearly CAR (black dots) for the 34 years without reported landslide activity.

The best results obtained for shallow landslide episodes correspond to the 5 days CAR (Fig. 11b). The envelope curve follows the exponential rule $D r=167.28 e^{-0.0355 \mathrm{CAR}}$, where $D r$ is the daily rainfall. There are only 5 no-landslide events lying above the curve (pink dots), confirming this rule as a possible threshold for the shallow slope movements. The best discrimination of deep landslide events is observed in the graph corresponding to the 30 days CAR (Fig. 11d). The combined threshold of daily rainfall $=16 \mathrm{~mm}$ and 30 days $\mathrm{CAR}=85 \mathrm{~mm}$ includes all the deep landslide episodes observed, and, equally important, it is exceeded by a single no-landslide event.

Differences on the relevance of antecedent rainfall for shallow and deep landslide episodes are also impressive when we compare the number of previous consecutive days with 30 days $C A R>50 \mathrm{~mm}$ (Table 3 ). This number ranges from 0 to 10 days for dates of shallow movements occurrence, and increases up to a minimum of 17-18 days for dates characterised by deep landslide activity. Moreover, maximum values (20 to 40 days) are observed in late event dates in those years characterized by several landslide episodes (e.g. 1989, 1996 and 2001).
4.4 Hydrological triggering conditions of shallow and deep landslides

Assessment of empirical rainfall thresholds provides no causal mechanisms for slope failures. Nevertheless, results from the statistical rainfall analysis are consistent with the different hydrological triggering conditions related to different types of landslides. Shallow translational soil slips are triggered by the rapid infiltration of water into the thin soil material (colluvium deposits) which overlies impermeable rocks. The temporary rise of the pore water pressure as well as the loss of soil apparent cohesion resulting from soil saturation are responsible for a critical reduction of the soil shear resistance and resultant failure (Gostelow, 1991; Iverson, 2000). Translational slides, rotational slides and complex and composite slope movements have deeper slip surfaces than soil slips and involve rocks and soils that yield small effective hydraulic diffusivities. They are triggered by the reduction of shear strength of affected soils and rocks, linked with the steady rising of the groundwater level resulting from long-term precipitation periods (Gostelow, 1991; van Asch et al., 1999; Iverson, 2000).

In the following section we describe the large-scale atmospheric circulation responsible for the high inter-annual precipitation variability and its effects on deep-seated landsliding (Fig. 8). 

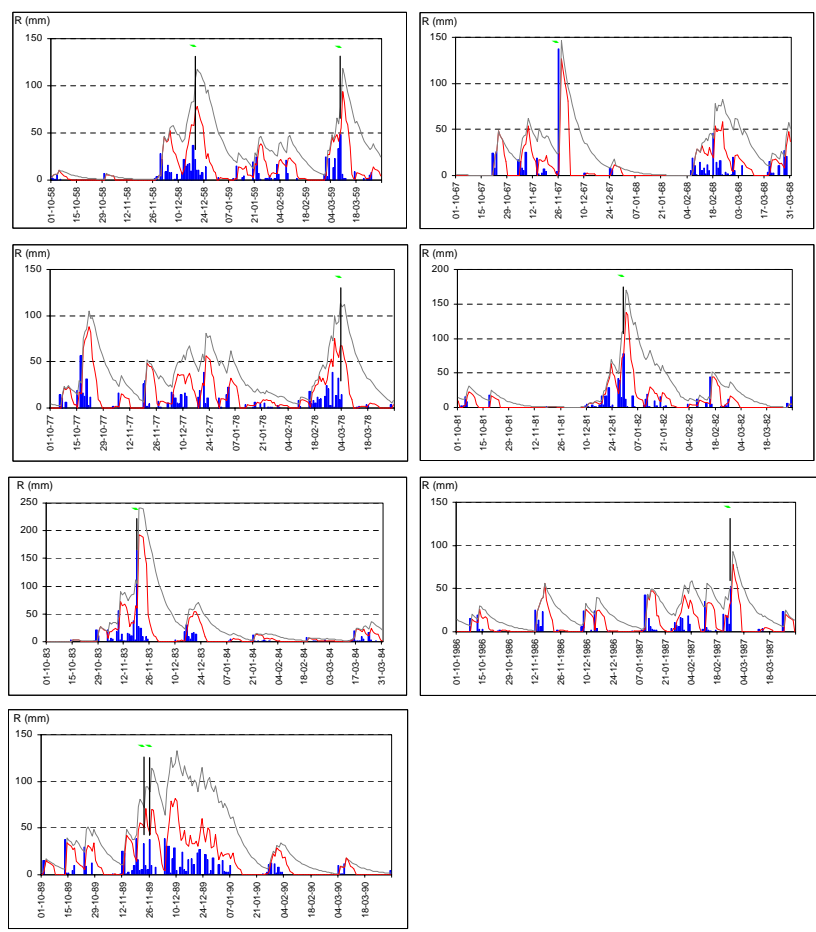

Fig. 9. Daily rainfall and calibrated antecedent rainfall (CAR) in the last 5 and 30 days for years of shallow landslide activity in the region north of Lisbon from 1956 to 2001 . Blue bars: daily rainfall; red curve: 5-days CAR; grey curve: 30 -days CAR; green diamonds: dates of shallow landslide activity.

\section{The impact of NAO on Portuguese precipitation and landslide occurrence}

It is now widely accepted that a large portion of winter precipitation in Iberia can be explained in terms of a relatively small number of large-scale atmospheric circulation modes that vary at monthly time scales (Trigo and Palutikof, 2001). In particular, the impact of the North Atlantic Oscillation (NAO) to model winter precipitation over Iberia has been documented in literature (e.g. Rodó et al., 1997; Corte-Real et al., 1998; Trigo et al., 2002; Trigo et al., 2004a, 2005). As previously referred at the beginning, the NAO corresponds to the major pattern of extratropical atmospheric variability, accounting for roughly one third of the sea level pressure variability in the Northern Hemisphere (Trigo et al., 2002; Hurrell et al., 2003).

The NAO index used in this study was developed by the Climatic Research Unit (University of East Anglia, UK) and is defined, on a monthly basis, as the difference between the normalized surface pressure at Gibraltar (southern tip of Iberian Peninsula) and Stykkisholmur in Iceland (Jones et al., 1997). The NAO index for winter months presents a positive trend over the last 30 years, as a consequence its distribution is dominated by positive values, with monthly averages above zero (Jones et al., 1997). Therefore we decided to normalize the entire winter NAO index (average of NDJFM values) so it has zero mean and standard deviation
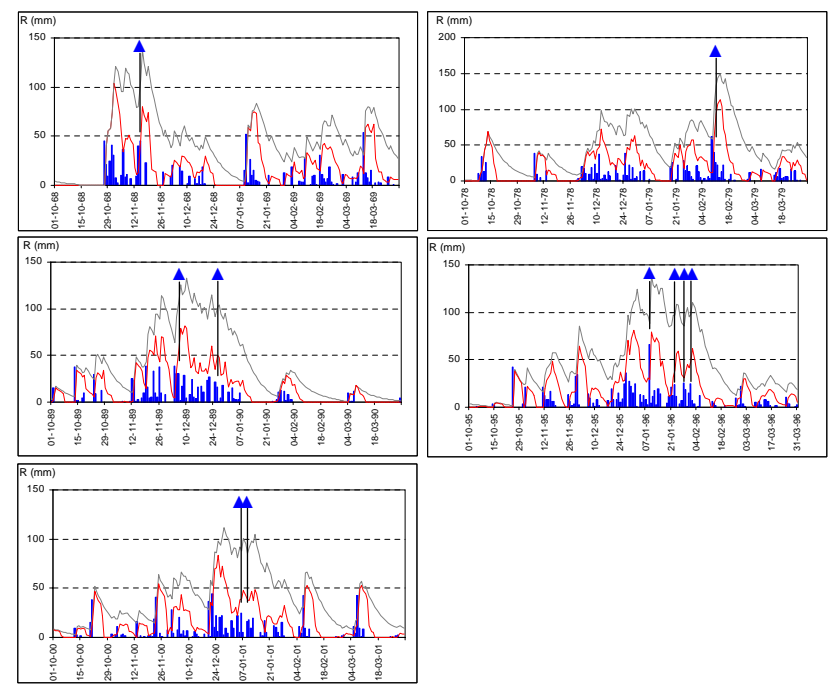

Fig. 10. Daily rainfall and calibrated antecedent rainfall (CAR) in the last 5 and 30 days for years of deep landslide activity in the region north of Lisbon from 1956 to 2001. Blue bars: daily rainfall; red curve: 5-days CAR; grey curve: 30-days CAR; blue triangles: dates of deep landslide activity.
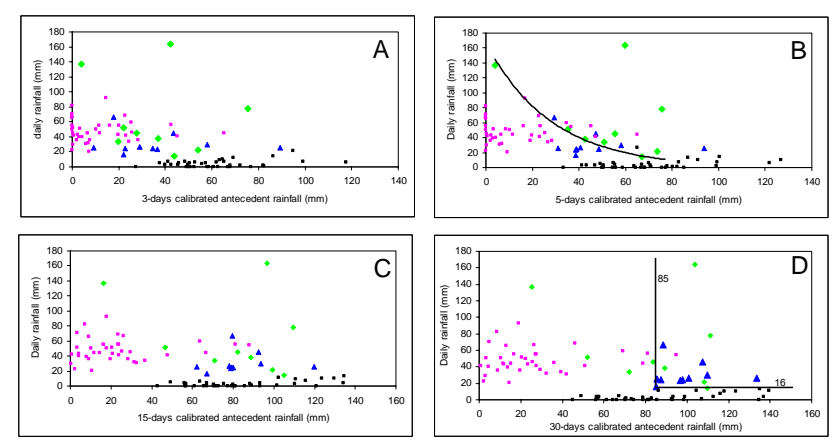

Fig. 11. Relationship between daily rainfall and calibrated antecedent rainfall (CAR) in 3 days (a), 5 days (b), 15 days (c) and 30 days (d) (period 1956-2001). Green diamonds: values associated to shallow landslides occurrence; blue triangles: values associated to deep landslides occurrence; small dots: values obtained from the yearly maximum daily rainfall (pink colour) and from the yearly maximum CAR (black colour), computed for years without reported landslides.

one. Finally, we defined the seasonal high NAO composite (low NAO composite) to be a combination of all winters with NAO index greater than 0.5 (less than -0.5). Between 1932 and 2001 (70 winters), the number of winter seasons with a high NAO index (20) is similar to the number characterized by a low NAO index (24). The remaining winters (26) are characterized by near normal NAO index values.

The spatial analysis on the impact of NAO on atmospheric circulation and precipitation is performed using monthly average values of sea level pressure (SLP), and precipitation rate $(\mathrm{mm} /$ day $)$ over a $2.5^{\circ} \times 2.5^{\circ}$ grid. The atmospheric data used in this study are large-scale gridded data retrieved from 

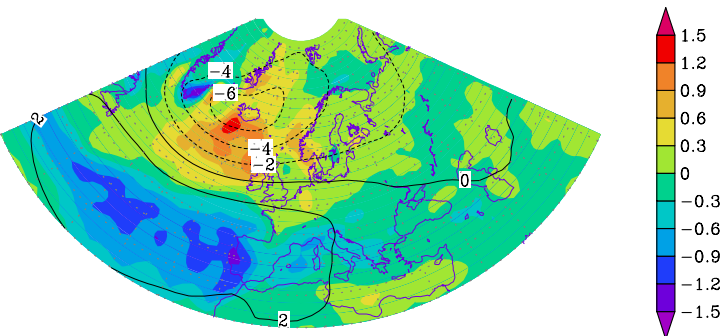

a

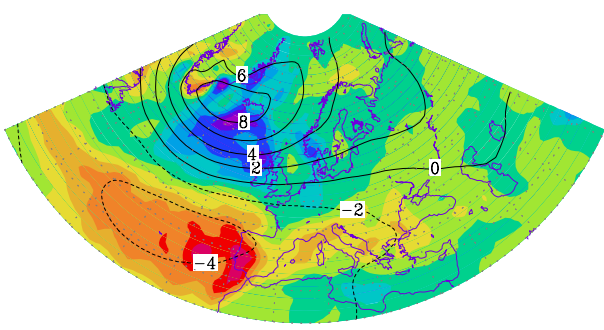

$\mathrm{b}$

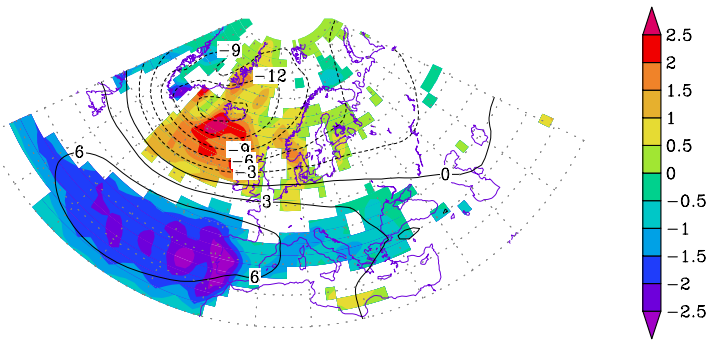

C

Fig. 12. Precipitation rate anomaly fields ( $\mathrm{mm} /$ day) from the NCEP/NCAR reanalysis for winter months with (a) high NAO index $>0.5$, (b) low NAO index $<-0.5$ and, and, (c) their difference (represented only if significant at the 5\% level). Positive (solid) and negative (dashed) isolines of the sea level pressure anomaly field (hPa) are also represented (period 1958-1997).

the National Centers for Environmental Prediction/National Center for Atmospheric Research (NCEP/NCAR) reanalysis dataset (Kalnay et al., 1996). Advantages and cautions on the use of this dataset for Iberia are beyond the scope in this work and have been previously addressed in greater detail by Trigo et al. $(2002,2004 a, b)$. The gridded data cover an area from $30^{\circ} \mathrm{N}$ to $80^{\circ} \mathrm{N}$ and $60^{\circ} \mathrm{W}$ to $70^{\circ} \mathrm{E}$, for the period 1958-1997. In fact, NCEP/NCAR Reanalyses does not cover the 70 years period available for the NAO index and precipitation in Portugal, therefore the spatial analysis presented in Fig. 12, as well as the storm track discussion in Sect. 6 (Fig. 16) is performed for a shorter 40 year long period. SLP and precipitation rate anomaly fields for winter months characterized by high and low NAO index values were computed and are shown in Figs. 12a and 12b, respectively. Differences of the SLP between winter months (NDJFM) with high and low NAO index (solid contour lines) are

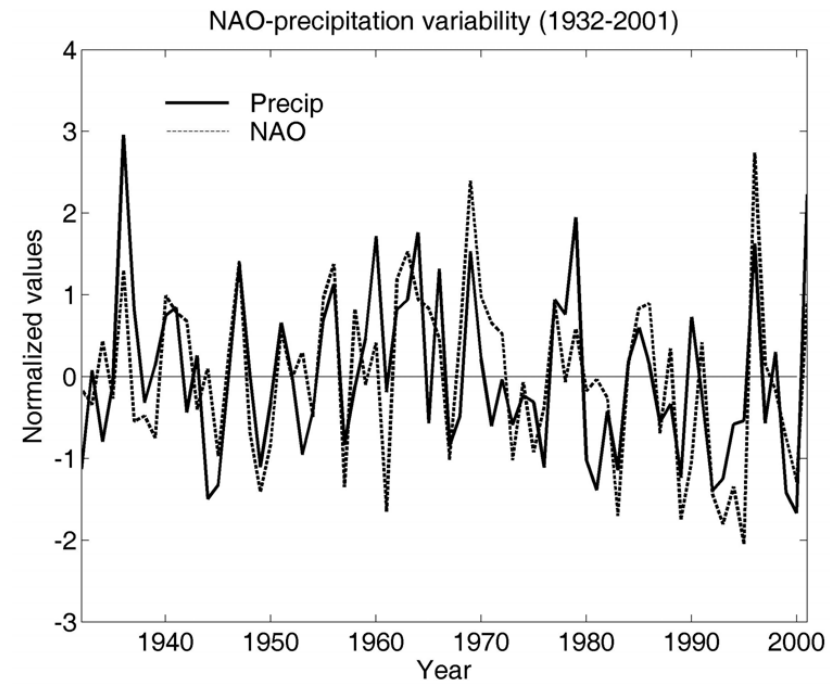

Fig. 13. Inter-annual variability of the mean winter (NDJFM) Portuguese average precipitation (solid curve), and the contemporaneous winter NAO index, multiplied by -1 to facilitate analysis (dashed curve); both curves have been normalised and so are dimensionless (period 1932-2001).

shown in Fig. 12c. Corresponding differences in precipitation rate, between high and low NAO composites, are also represented in Fig. 12c, wherever those differences are statistically significant at the $5 \%$ level (colour scale). This figure highlights two important issues:

(i) The impact of the NAO on the northern hemisphere winter precipitation field, for both phases of the NAO index, is not restricted to the European continent but extends over large sectors of the North Atlantic, confirming results from previous works (Hurrell, 1995; Osborn et al., 1999; Trigo et al., 2004a);

(ii) Figure $12 \mathrm{c}$ shows quasi-zonal bands of opposite anomaly signs, with impressive positive differences concentrated in the northern latitudes, extending from eastern Greenland to Finland, with maximum values south of Iceland. At lower latitudes, a strong band of negative differences extends from the Azores archipelago in the mid Atlantic Ocean, to the Balkanic Peninsula, with larger differences located west of Iberia, and particularly over Portugal.

The inter-annual variability of Portuguese average winter (NDJFM) precipitation and contemporaneous winter NAO index can be observed, for the 1932-2001 period in Fig. 13 . The average precipitation in Portugal was computed using 18 stations that cover the whole period and are representative of the entire territory (Trigo and DaCamara, 2000). Both curves (precipitation and NAO index) were normalized and the NAO index multiplied by minus one to facilitate visual comparisons. The correlation coefficient between both curves is $R=-0.66$ (statistically significant at the $1 \%$ level).

Having shown that the winter precipitation in Portugal is associated with the NAO mode we now focus our attention on the precipitation that falls on SJT. For this pur- 

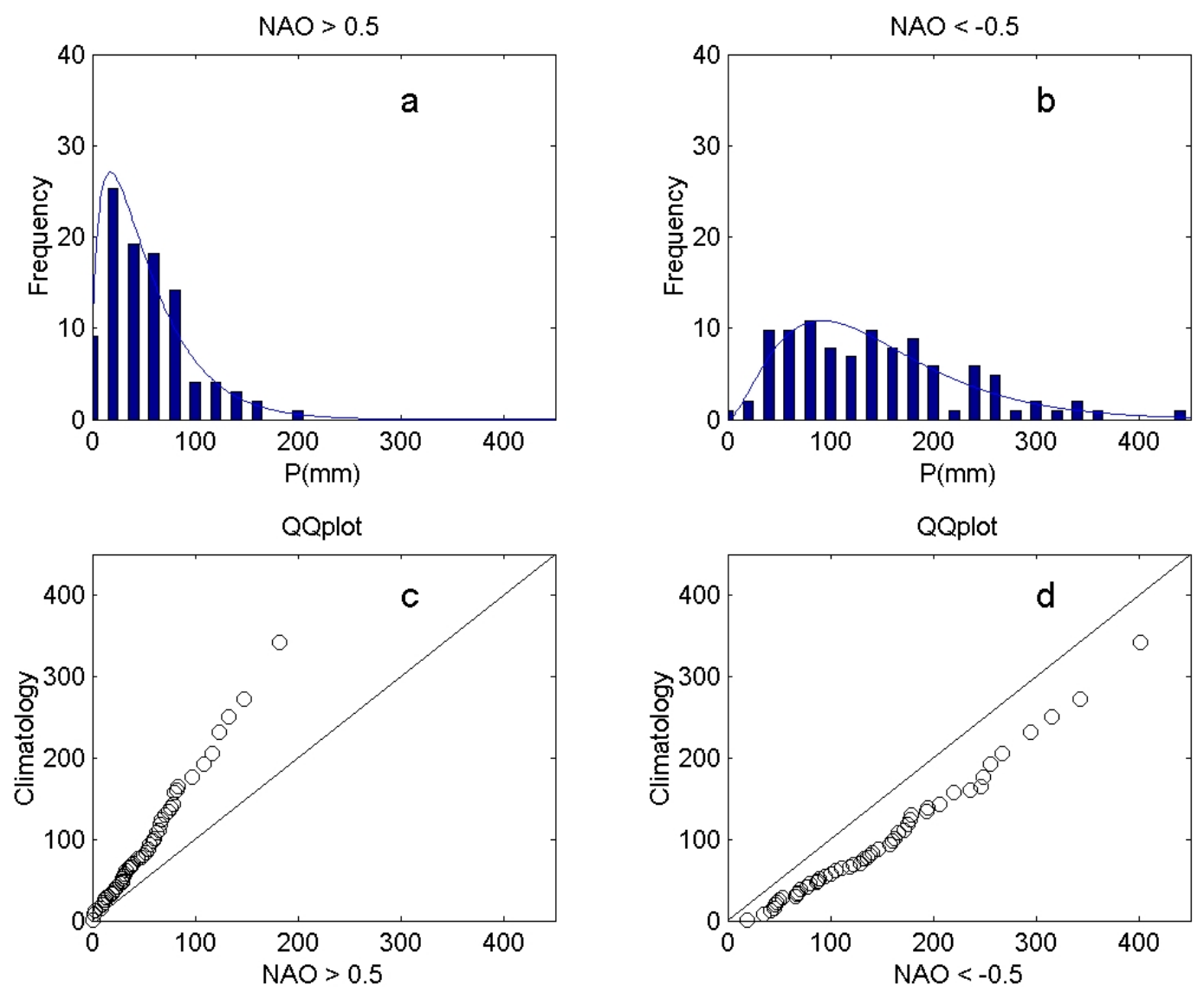

Fig. 14. Histograms of monthly precipitation for the reference rain gauge station of S. Julião do Tojal (SJT) for winters with (a) high NAO index $(>0.5)$ and, (b) low NAO index $(<-0.5)$. The corresponding gamma function is also represented (solid curve). QQ-plots comparing percentiles of the empirical cumulative distribution function for the climatological normals for (c) high NAO index and, (d) low NAO index (period 1939-2001).

pose we use available monthly rainfall from November to March, at SJT, between 1939 and 2001 (63 winters, corresponding to 315 cases), a period slightly shorter than the available period for Portugal. Composites were constructed on a monthly basis with the high NAO composite containing months with the monthly NAO normalized index greater than 0.5 (99 cases) and low NAO composite containing those months with the NAO index less than -0.5 (102 cases). The remaining months are characterized by "near normal" values of the NAO index. The histogram of monthly precipitation for the high (low) NAO composites is represented in Fig. 14a (Fig. 14b). A gamma distribution was fit to each composite precipitation distribution, using the standard method of maximum likelihood (Trigo et al., 2005). These adjusted gamma distributions show that the probability of a very dry month during the negative phase of the NAO is small, while it presents high values, for the positive phase. In contrast, the probability of a very wet month is virtually null for the positive NAO class and increases considerably for months characterized by low NAO index. In a previous work we have showed that the probability of a wet month (above the $90 \%$ percentile) for months with NAO index below -0.5 is roughly 20 times higher than the corresponding probability for months with NAO index above 0.5 (Trigo et al., 2005). The use of quantile-quantile (QQ)-plots helps to identify the range of values where the high (Fig. 14c) and low (Fig. 14d) NAO composites differ more markedly from the climatological mean. These QQ-plots compare percentiles of the empirical cumulative distribution function of the climatological mean and the high and low NAO composites (Wilks, 1995). If the match is perfect, the plotted points will fall along the straight line in Figs. 14c and 14d. Points that lie above (below) this line indicate that the percentiles associated with the NAO composites are lower (higher) than those associated with the entire distribution. This analysis shows that the high NAO index composite gets further and further away as we move from low to the highest percentiles (Fig. 14c). In the case of the low NAO index composite the cumulative distribution function is consistently higher than the corresponding winter climatological distribution (Fig. 14d).

In order to associate precipitation, NAO and landslide occurrence we have applied a 3-month moving average to both the NAO index and the monthly SJT precipitation time series during the wet season only (NDJFM). However, we do not 


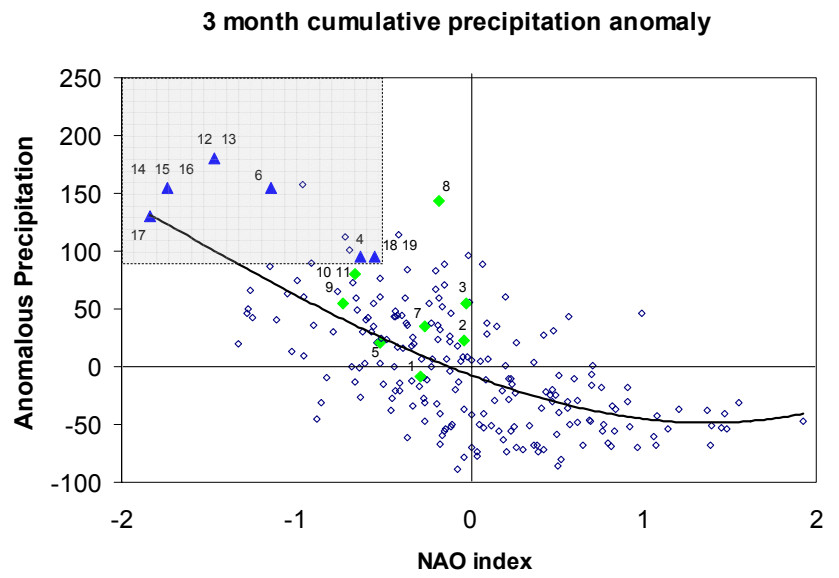

Fig. 15. Scatter plot between 3-month moving average NAO index and associated anomalous precipitation at SJT for the winter (NDJFM) months, (period 1956-2001, 225 months). Small diamonds: months with no landslide episodes reported. Green diamonds: months with shallow landslide episodes. Blue triangles: months with deep landslide episodes. Numbers next to green and blue symbols represent the landslide episode number as given in Table 2.

use the raw SJT values, instead we compute the monthly average (computed for the entire period 1939-2001). Then, we subtract the average monthly values to obtain a time series of monthly anomalies, i.e. monthly departures from the mean climatological values. October values are used to compute November and December averages. September values are excluded from any forthcoming analysis because the NAOprecipitation relationship for summer months is weak (Trigo at al., 2004a). Therefore, values for January of a generic year $n$, correspond to the anomalous rainfall and NAO index averages computed between November of year $n-1$ and January of year $n$, while values for November of any year are restricted to the October and November values for that same year. For landslides episodes that have occurred in the first 5 days of the month we only considered the NAO index and precipitation values from the previous two months (episodes \#5, \#12 and \#17). The scatter plot between 3-month moving average NAO and anomalous precipitation can be observed in Fig. 15. Numbers close to green and blue symbols represent the landslide episode number reported in Table 2. This figure reveals a relatively good linear relationship between variables (linear correlation is -0.63 , significant at the $1 \%$ level). However, this link is slightly better represented by a non-linear curve, such as the 3 rd order polynomial curve also shown $(R=-0.65)$. All months during which landslides occurred are characterized by negative values of the averaged NAO index. All months, except two, where landslide events were reported are located above the polynomial fitting curve and also present a positive 3-month average value of precipitation anomaly. Months characterized by the occurrence of multiple events (e.g. episodes \#12 to \#17) included in group 2 of deep-seated landslides reveal particularly intense negative average values of the NAO index (lower than -1) and

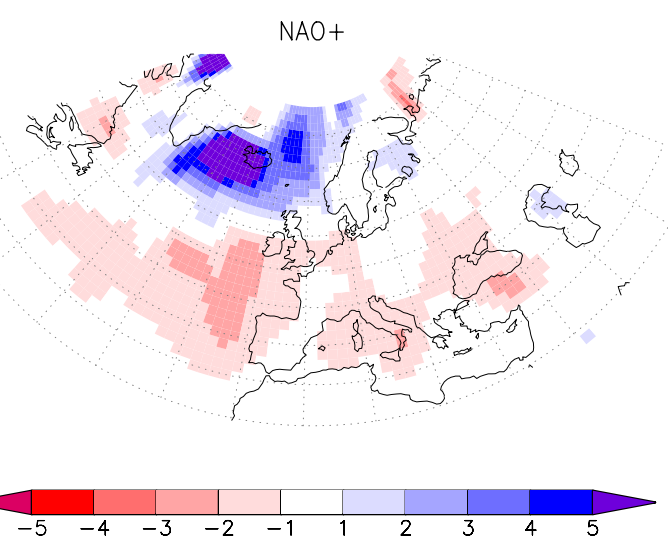

(a)

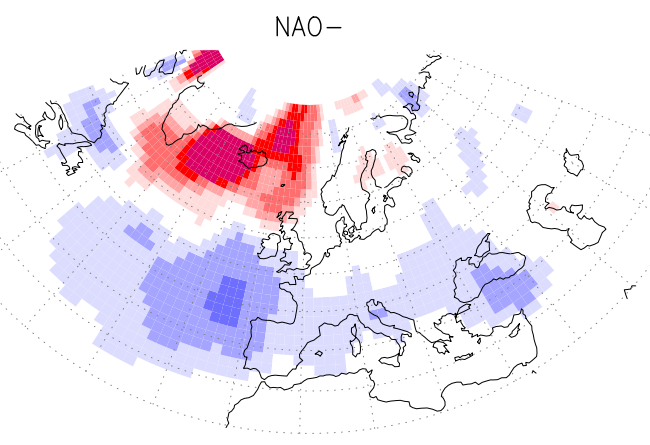

(b)

Fig. 16. Number of cyclones per winter, detected within boxes of $5^{\circ}$ lon $\times 5^{\circ}$ lat and normalised for $50^{\circ} \mathrm{N}$, for (a) $\mathrm{NAO}>0.5$ and, (b) $\mathrm{NAO}<-0.5$ (period 1958-1997).

extremely high values of average anomalous precipitation.

In the following section we will show that the control exerted by NAO on the precipitation regimes is related to the corresponding changes in the North-Atlantic storm paths that affect the western European coast.

\section{The impact of NAO on storms affecting the Iberian Peninsula}

There are several objective methodologies that have been developed to detect the regions of storm development (cyclogenesis) and decay (cyclolysis), as well as the paths of individual storms (Serreze et al., 1997; Blender et al., 1997; Trigo et al., 1999). Here, the detection and tracking of North Atlantic cyclones is based on an algorithm first developed for the Mediterranean Region by Trigo et al. $(1999,2002)$ and recently adapted to the entire north Atlantic area (Trigo et al., 2004b). Both the detection and tracking schemes were performed using 6-hour sea level pressure (SLP), available from NCEP/NCAR reanalysis on a $2.5^{\circ} \times 2.5^{\circ}$ grid. Again, these data cover the area from $30^{\circ} \mathrm{N}$ to $80^{\circ} \mathrm{N}$ and $60^{\circ} \mathrm{W}$ to $70^{\circ} \mathrm{E}$, and the period from 1958 to 1997 . Cyclones are identified as minima in SLP fields, fulfilling a set of conditions regarding the central pressure (less than $1020 \mathrm{hPa}$ ) and the pressure gradient, averaged over an area of about $1100^{2} \mathrm{~km}^{2}$, has to be at least $0.55 \mathrm{hPa} / 100 \mathrm{~km}$. The tracking is based on a near- 
est neighbor search in consecutive charts, assuming that the speed of individual storms is less than $50 \mathrm{~km} / \mathrm{h}$ in the westward direction, and $110 \mathrm{~km} / \mathrm{h}$ in any other. Further details on the cyclone detecting and tracking method may be found in Trigo et al. (1999, 2002), and Trigo et al. (2004b).

The anomalies of the average number of cyclones detected per winter, per $5^{\circ} \times 5^{\circ}$ cell normalized for $50^{\circ} \mathrm{N}$, are plotted in Figs. 16a and 16b, for high NAO and low NAO composites, respectively. As expected, during high NAO episodes there is a pronounced decrease in the number of cyclones traveling between the Azores (mid Atlantic ocean) and the Iberian Peninsula. This area of fewer than average storms extends to part of the Northern Mediterranean and the Black Sea. The negative anomaly to the west of Iberia represents a decrease of over $60 \%$ of storm-tracks, when compared with the climatological mean. During the high phase of the NAO, the dominant cyclone paths are located between Greenland and the Scandinavia Peninsula. On the contrary, during months characterized by low NAO index, there are more than the usual number of cyclones traveling along a more south-easterly trajectory, between the Iberian Peninsula and the Caspian Sea. Again the impact over western Iberia is particularly pronounced, with the anomaly maximum of the NAO negative phase representing a relative increase of more than $80 \%$, with respect to the climatological average.

It is important to keep in mind that this type of algorithm identifies and follows cyclone centers, and thus the anomalies described above (Figs. 16a and 16b) also correspond to densities of storm centers. Therefore, their associated impact on precipitation extends to the south of each main maximum/minimum shown, accompanying the main fronts associated with the synoptic systems tracked by the algorithm. In fact the maximum impact of NAO in precipitation anomalies (Fig. 12) is located a few degrees south of the corresponding storm centers density anomalies shown in Fig. 16.

\section{Discussion and conclusions}

Rainfall induced landslides are known to occur in the Lisbon area with moderate frequency and have been catalogued since the late 1950s. Shallow translational soil slips have been related to intense rainfall periods ranging from 1 to 15 days, while deep slope movements (translational slides, rotational slides and complex and composite slope movements) have been occurred in relation to longer periods of less intense rain, lasting from 30 to 90 days. Intense rainfall is responsible by the rapid growth of pore pressure and by the loss of the apparent cohesion of thin soils, resulting in failure within the soil material or at the contact with the underlying impermeable bedrock. Long duration less intense rainfall periods allow the steady rise of the groundwater table and the occurrence of deep failures through the reduction of shear strength of affected materials.

Daily precipitation data for SJT was used to derive a useful exponential law relating rainfall intensity and the rainfall critical duration for the 19 reported landslide events.
The fitting of the curve to the 19 points looks impressive $\left(R^{2}=0.88\right)$, namely for those landslide episodes corresponding to long-lasting rainfall periods. The distinction between landslide types concerning the number of days relevant to the antecedent rainfall was confirmed combining the daily rainfall and the calibrated antecedent rainfall (CAR) from 3 to 30 days. We identified an exponential rule $\left(D r=167.28 e^{-0.0355 \mathrm{CAR}}\right)$ for the 5 days CAR which is a threshold for shallow landslide episodes, while deep landslide events are better discriminated by a combined threshold of daily rainfall $=16 \mathrm{~mm}$ and 30 days $C A R=85 \mathrm{~mm}$. The group of deep landslide episodes is the most likely to present a direct relationship with the NAO mode of atmospheric circulation.

We have shown that the North Atlantic Oscillation impact on precipitation in Portugal is important and is the main driving force for the high values of inter-annual variability that characterize the Portuguese precipitation regime. Most winters considered wetter (drier) than normal correspond to winters characterized by a negative (positive) NAO index. In particular, for the reference station of SJT, near the landslide studied areas, the probability of a wet month increases considerably for months with negative NAO index. During these months with negative NAO index, the frequency of stormtracks over the west of Iberia increases more than $80 \%$, when compared with the climatological mean.

Precipitation, NAO and landslide occurrence were associated through a 3-month moving average computed to both the NAO index and the monthly rainfall anomalies. This analysis has shown that months characterized by the occurrence of deep-seated landslides (group 2) have very high values of average anomalous precipitation and intense negative average values of the NAO index. However, shallow landslide episodes, characteristic of group 1 , are not critically associated with the NAO phenomena.

Results obtained from the present analysis reveal the necessity to separate the rainfall-landslide analysis for shallow and deep events due to considerable differences in triggering physical mechanisms and associated threshold values of critical antecedent rainfall and rainfall intensity. Furthermore, these results point for the possibility of wide scope for further work on landslide hazard assessment at a regional scale, considering the possibility of NAO-based long-term rainfall forecast models. In fact, information from such models can be coupled with landslide susceptibility models, providing the temporal dimension needed for landslide hazard assessment based on probabilistic approaches. This can be accomplished if we assume that rainfall amount - durations or rainfall intensities that produced slope instability in the past within the study area will produce the same effects each time they occur in the future (i.e. same type of landslides and similar total affected areas).

Acknowledgements. The Reanalyses data have been produced by the NCEP and NCAR DSS. The window $\left(30^{\circ} \mathrm{N}-80^{\circ} \mathrm{N}, 60^{\circ} \mathrm{E}-\right.$ $70^{\circ} \mathrm{W}$ ) has been extracted and kindly provided by I. Harris and D. Viner (CRU). Precipitation data for São Julião do Tojal 
was provided by INAG. This work was supported by the Portuguese Science Foundation (FCT) through project VAST (Variability of Atlantic Storms and Their impact on land climate) POCTI/CTA/46573/2002, co-financed by the European Union under program FEDER, and by the European Commission through the project ALARM (Assessment of Landslide Risk and Mitigation in Mountain Areas), contract EVG1-CT-2001-00018.

Authors are grateful to J. Godt whose pertinent comments and suggestions improved the quality of this paper.

Edited by: G. B. Crosta

Reviewed by: J. Godt and another referee

\section{References}

Barnston, A. G. and Livezey, R. E.: Classification, Seasonality and Persistence of Low-Frequency Atmospheric Circulation Patterns, Mon. Wea. Rev. 115, 1083-1127, 1987.

Blender, R. K., Fraedrich, K., and Lunkeit, F.: Identification of cyclone track regimes in the North Atlantic, Quart. J. Roy. Met. Soc., 123, 727-741, 1997.

Canuti, P., Focardi, P., and Garzonio, C. A.: Correlation between rainfall and landslides, Bulletin International Association Engineering Geology, 32, 49-54, 1985.

Capecchi, F. and Focardi, P.: Rainfall and landslides: Research into a critical precipitation coefficient in an area of Italy, in: Landslides, edited by: Bonnard, C., Proceedings of the Fifth International Symposium on Landslides, Balkema, Rotterdam, 2, 11311136, 1988.

Coe, J. A., Godt, J. W., and Wilson, R. C.: Distribution of debris flows in Alameda County, California triggered by 1998 El Niño rainstorms: a repeat of January 1982, EOS, 79, 45, 266, 1998.

Corominas, J.: Landslides and climate, Keynote Lectures from the 8th International Symposium on Landslides 4, 1-33, 2001.

Corte-Real J., Qian, B., and Xu, H.: Regional climate change in Portugal: precipitation variability associated with large-scale atmospheric circulation, Int. J. Climatol., 18, 619-635, 1998.

Crozier, M.: Landslides: causes, consequences and environment, Croom Helm, London, 252, 1986.

Ferreira, A. B. and Zêzere, J. L.: Portugal and the Portuguese Atlantic Islands, in: Geomorphological Hazards of Europe, edited by: Embleton, C. and Embleton-Hamann, C., Developments in Earth Surface Processes 5, Elsevier, 391-407, 1997.

Ferreira, A. B., Zêzere, J. L., and Rodrigues, M. L.: Instabilité des versants dans la région au Nord de Lisbonne, Essai de cartographie géomorphologique, Finisterra, XXII, 43, 227-246, 1987.

Fukuoka, M.: Landslides associated with rainfall, Geotechnical Engineering, 11, 1-29, 1980.

Gámiz-Fortis, S., Pozo-Vázquez, D., Esteban-Parra, M. J., and Castro-Díez. Y.: Spectral characteristics and predictability of the NAO assessed through Singular Spectral Analysis, J. Geophys. Res., 107, 1029, doi:10.1029/2001JD00136, 2002.

Glade, T., Crozier, M., and Smith, P.: Applying probability determination to refine landslide triggering rainfall thresholds using empirical "Antecedent daily rainfall model", Pure and Applied Geophysics, 157, 1059-1079, 2000.

Godt J. W.: Maps showing locations of damaging landslides caused by El Niño rainstorms, winter season 1997-1998, San Francisco Bay region, California, USGS http://pubs.usgs.gov/mf/ 1999/mf-2325/, 1999.
Gostelow, P.: Rainfall and landslides, in: Prevention and control of landslides and other mass movements, edited by: AlmeidaTeixeira, M. et al., CEC, Bruxels, 139-161, 1991.

Gumbel, E. J.: Statistics of extremes. Columbia University Press, New York, 1958.

Hurrell, J. W.: Decadal trends in the north Atlantic oscillation: regional temperatures and precipitation, Science, 269, 676-679, 1995.

Hurrell, J. W., Kushnir, Y., Ottersen, G., and Visbeck, M. (Eds.): The North Atlantic Oscillation: Climatic Significance and Environmental Impact, Geophysical Monograph Series, 134, 279, 2003.

Iverson, R. M.; Landslide triggering by rain infiltration, Water Resources Research, 36, 7, 1897-1910, 2000.

Jones, P. D., Jonsson, T., and Wheeler, D.: Extension to the North Atlantic Oscillation using instrumental pressure observations from Gibraltar and south-west Iceland, Int. J. Climatol., 17, 1433-1450, 1997.

Kalnay, E., Kanamitsu, M., Kistler, R., Colins, W., Deaven, D., Gandin, L., Iredell, M., Saha, S., White, G., Wollen, J., Zhu, Y., Leetmaa, A., Reynolds, R., Chelliah, M., Ebisuzaki, W., Higgins, W., Janowiak, J., Mo, K. C., Ropelewski, C., Wang, J., Jennem R., and Joseph, D..: The NCEP/NCAR 40-years reanalyses project. Bull. Am. Meteorol. Soc. 77, 437-471, 1996.

Ngecu, W. M. and Mathu, E. M.: The El-Niño triggered landslides and their socioeconomic impact in Kenya, Environmental Geology, 38, 277-284, 1999.

Osborn, T. J., Briffa, K. R., Tett, S. F. B., Jones, P. D., and Trigo, R.M.: Evaluation of the North Atlantic Oscillation as simulated by a climate model, Clim. Dyn., 15, 685-702, 1999.

Philip, J. R.: Hillslope infiltration: Planar slopes, Water Resources Research, 27, 1, 109-117, 1991.

Qian, B., Corte-Real, J., and Xu, H.: Is the North Atlantic Oscillation the most important atmospheric pattern for precipitation in Europe?, J. Geophys. Res., 105, 11 901-11 910, 2000.

Rodó, X., Baert, E., and Comin, F. A.: Variations in seasonal rainfall in Southern Europe during the present century: relationships with the North Atlantic Oscillation and the El Niño-Southern Oscillation, Clim. Dyn., 13, 275-284, 1997.

Rodrigues, L. F. and Coelho, A. G.: Landslides in Portugal - extent and economic significance, in: Landslides: Extent and Economic Significance, edited by: Brabb, E. and Harrod, B., Balkema, 179-189, 1989.

Rodriguez-Fonseca, B. and Castro, M.: On the connection between winter anomalous precipitation in the Iberian Peninsula and North West Africa and the Summer subtropical Atlantic sea surface temperature, Geophy. Res. Lett., 29, 1863, doi:10.1029/2001GL014421, 2002.

Rogers, J. C.: The association between the North Atlantic Oscillation and the Southern Oscillation in the Northern Hemisphere, Mon. Wea. Rev., 112, 1999-2015, 1984.

Serreze, M. C., Carse, F., Barry, R. G., and Rogers, J. C.: Icelandic Low cyclone activity: climatological features, linkages with the $\mathrm{NAO}$, and relationships with recent changes in the Northern Hemisphere circulation, J. Clim., 10, 453-464, 1997.

Trigo, I. F., Trevor, D. D., and Grant, R. B.: Objective climatology of cyclones in the Mediterranean region, J. Clim., 12, 16851696, 1999.

Trigo, I. F., Grant, R. B., and Trevor, D. D.: Climatology of cyclogenesis mechanisms in the Mediterranean, Mon. Wea. Rev., 130, 549-569, 2002. 
Trigo, R. M. and DaCamara, C. C.: Circulation Weather Types and their impact on the precipitation regime in Portugal, Int. J. Climatol., 20, 1559-1581, 2000.

Trigo, R. M. and Palutikof, J. P.: Precipitation scenarios over Iberia: a comparison between direct GCM output and different downscaling techniques, J. Clim., 14, 4422-4446, 2001.

Trigo, R. M., Osborn, T. J., and Corte-Real, J.: The North Atlantic Oscillation influence on Europe: climate impacts and associated physical mechanisms, Clim. Research, 20, 9-17, 2002.

Trigo, R. M., Pozo-Vazquez, D., Osborn, T. J., Castro-Diez, Y., Gámis-Fortis, S., and Esteban-Parra, M. J.: North Atlantic Oscillation influence on precipitation, river flow and water resources in the Iberian Peninsula, Int. J. Climatol., 24, 925-944, 2004a.

Trigo, R. M., Trigo, I. M., DaCamara, C. C., and Osborn, T. J.: Winter blocking episodes in the European-Atlantic sector: climate impacts and associated physical mechanisms in the Reanalysis, Climate Dynamics, 23, 17-28, 2004b.

Trigo, R. M., Zêzere, J. L., Rodrigues, M. L., and Trigo, I. F.: The influence of the North Atlantic Oscillation on rainfall triggering of Landslides near Lisbon, Natural Hazards, Kluwer Publishers, in press, 2005.

van Asch, T., Buma, J., and VanBeek, L.: A view on some hydrological triggering systems in landslides, Geomorphology, 30, 1-2, 25-32, 1999.

van Loon, H. and Rogers, J. C.: The seesaw in winter temperatures between Greenland and Northern Europe, Part 1: general description, Mon. Wea. Rev., 106, 296-310, 1978.
Walker, G. T.: Correlations in seasonal variations of weather, IX Mem. Ind. Meteorol. Dept., 24, 275-332, 1924.

Wilks, D. S.: Statistical Methods in the Atmospheric Sciences: an introduction, International Geophysical Series, Academic Press, 59, 464, 1995.

Zêzere, J. L.: Rainfall triggering of landslides in the Area North of Lisbon, In: Landslides in Research, Theory and Practice, Edited by: Bromhead, E., Dixon, N., and Ibsen, M., London, Thomas Telford, 3, 1629-1634, 2000.

Zêzere, J. L.: Landslide susceptibility assessment considering landslide typology, A case study in the area north of Lisbon (Portugal), Nat. Haz. Earth Sys. Sci., 2, 73-82, 2002,

SRef-ID: 1684-9981/nhess/2002-2-73.

Zêzere, J. L., Ferreira, A. B., and Rodrigues, M. L.: The role of conditioning and triggering factors in the occurrence of landslides: a case study in the area north of Lisbon (Portugal), Geomorphology, 30, 1-2, 133-146, 1999a.

Zêzere, J. L., Ferreira, A. B., and Rodrigues, M. L.: Landslides in the North of Lisbon Region (Portugal): Conditioning and Triggering factors, Physics and Chemistry of the Earth (Part A), 24, 10, 925-934, 1999b.

Zêzere, J. L. and Rodrigues, M. L.: Rainfall Thresholds for Landsliding in Lisbon Area (Portugal), In: Landslides, Edited by: Rybar, J., Stemberk, J., and Wagner, P., A. A. Balkema, Lisse, 333338, 2002. 